\title{
SOIL ORGANIC MATTER QUALITY, STRUCTURE AND ACTIVITY OF THE DENITRIFIERS COMMUNITY AS INFLUENCED BY DECAYING MULCHED CROP RESIDUES
}

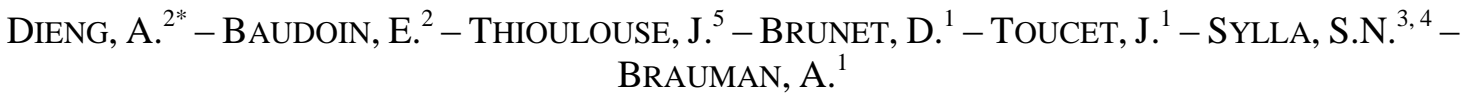 \\ ${ }^{1}$ Institut de Recherche pour le Développement (IRD), UMR Eco\&Sols, 34060 Montpellier, \\ France \\ ${ }^{2}$ IRD, UMR Eco\&Sols, Laboratoire d'Ecologie Microbienne des Sols et Agroécosystèmes \\ Tropicaux, BP 1386, 18524 Dakar, Senegal \\ ${ }^{3}$ Laboratoire Commun de Microbiologie, (IRD/ISRA/UCAD), BP 1386, 18524 Dakar, Senegal \\ ${ }^{4}$ Université Cheikh Anta Diop, Département de Biologie Végétale, BP 5005, Fann, Dakar, \\ Senegal \\ ${ }^{5}$ Université de Lyon, F-69000, Lyon, Université de Lyon 1, CNRS UMR5558, Laboratoire de \\ Biométrie et Biologie Evolutive, F-69622 Villeurbanne, France \\ *Corresponding author \\ e-mail: a.dieng@hotmail.com; phone: +221-338-493-325; fax: +221-338-493-302 \\ present address : Laboratoire Commun de Microbiologie, (IRD/ISRA/UCAD), BP 1386, 18524 \\ Dakar, Senegal \\ (Received 22 $2^{\text {nd }}$ Aug 2014; accepted 28 $8^{\text {th }}$ Oct 2014)
}

\begin{abstract}
Our experiment evaluated the effect of maize and peanut mulched residues upon soil organic matter and denitrifying community over a five-week incubation in soil microcosms. Soil organic matter under peanut and maize debris contrasted in biochemical quality throughout incubation, despite identical soil $\mathrm{C}$ contents that were significantly increased by both organic amendments. Moreover, only soluble extracts originating from the peanut treated soils could significantly fuel semi-potential denitrification. Accordingly, the composition of the nirK and nosZ communities was also specifically affected by mulch type, and the strongest impact was registered within the nos $Z$ gene-bearing denitrifiers under peanut residues. Residue enriched soils displayed temporal patterns of potential denitrification activity that were also dependant on residue type. The highest overall emission rates were recorded with soils under maize mulch but they were not mirrored by direct $\mathrm{N}_{2} \mathrm{O}$ contents of the microcosm's headspace. Overall, both soil organic matter and denitrifiers community changes were conditioned throughout the decomposition kinetics by the original quality of mulched crop residues. However, the denitrification activity was decoupled both from the composition of the denitrifying community and from the soil organic matter quality.
\end{abstract}

Keywords: soil denitrification, mulched crop residues, dissolved organic matter, nitrous oxide

\section{Introduction}

Nitrous oxide constitutes around 6\% of the greenhouse effect (Bouwman, 1998) and contributes to the depletion of the stratospheric ozone (Tabazadeh et al., 2000). In 2005, agriculture was estimated to account for about $60 \%\left(2.8 \mathrm{Gt} \mathrm{CO}_{2}\right.$-eq $\left.\mathrm{yr}^{-1}\right)$ of global $\mathrm{N}_{2} \mathrm{O}$ anthropogenic emissions (IPCC, 2007). Organic fertilization with animal wastes and crop residues has been identified as a potent factor responsible for agricultural $\mathrm{N}_{2} \mathrm{O}$ emissions. In soil, $\mathrm{N}_{2} \mathrm{O}$ is released as a by-product mainly during the biological 
processes of nitrification and/or denitrification according to the water soil content. There is a consensual body of evidence in literature to identify bacterial denitrification as the predominant process of $\mathrm{N}_{2} \mathrm{O}$ production when water-filled pore space values become higher than 60\% (Bouwman, 1998; Bateman and Baggs, 2005).

The stimulating effects of organic fertilization on denitrification rates have been identified for long (Mosier et al., 1991; Philippot et al., 2007). The extent and temporal pattern of gaseous $\mathrm{N}$ losses often appear to be governed by the biochemical quality of the organic inputs, their placement and loading rates. In particular, crop residues with low $\mathrm{C}: \mathrm{N}$ ratios, such as that of legume, are often considered to trigger higher $\mathrm{N}_{2} \mathrm{O}$ emissions (Baggs et al., 2001; Huang et al., 2004; Millar et al., 2004) by delivering more readily available $\mathrm{N}$ compounds to soil microorganisms. Conversely, plant materials with high lignin or polyphenol contents were shown to lower these nitrogen losses by decreasing $\mathrm{N}$ availability for the involved microbial processes (Palm et al., 1991; Millar and Baggs 2004; Garcia-Ruiz and Baggs 2007). As soil dissolved organic matter (DOM) mainly originates from litter and humus, it can be influenced by crop residues retention and further impacts on microbial processes (Kalbitz et al., 2000; Chantigny, 2003). DOM is known to stimulate microbial growth as exemplified with the soluble fraction of labelled ryegrass residues whose carbon was shown to be incorporated into the soil microbial biomass (McMahon et al., 2005). A stimulating role of DOM in the denitrification process was already observed with mineral soils amended with DOM extracted from organic soils (Katz et al., 1985). Moreover, the in vitro nitrate reductase activity level of an Azospirillum brasilense strain proved to be dependant on the type of soluble carbon sources (Sadasivan and Neyra, 1988). More recently, a range of single $C$ substrates of increasing recalcitrance also proved to differentially impact on soil potential denitrification (Murray et al., 2004). Several studies reporting on detritusphere, defined as the soil layer influenced by the adjacent litter, have evidenced that diverse microbial activities (e.g. respiration, xylanase, phosphatase, protease) were strongly enhanced along a sharp gradient from the soil surface in response to soluble organic substances released from the residues into the soil poral network (Gaillard et al., 1999; Kandeler et al., 1999; Poll et al., 2006). Such a stimulation of microbial activities in the detritusphere is likely to lower oxygen concentration and generate simple organic molecules that would be both beneficial to denitrification.

While numerous studies aimed to estimate the impact of organic inputs on $\mathrm{N}$ losses by denitrification, little research has been performed to explore the functional link between denitrification activity and denitrifying community composition and/or size. A reference in vitro study however clearly stated that the $\mathrm{N}_{2} \mathrm{O} / \mathrm{N}_{2}$ ratio of $\mathrm{N}$ losses could be altered according to the diversity of the denitrifiers isolates (Cavigelli and Robertson, 2000, 2001). Since then a few in situ investigations have characterized how organic fertilization can impact the denitrifying community structure and activity (Enwall et al., 2005; Dambreville et al., 2006; Patra et al., 2006) but have failed to evidence any robust link between these community traits. Therefore, there is still a need to clarify to which extent the biochemical characteristics of organic inputs are likely to influence the denitrification rates and $\mathrm{N}_{2} \mathrm{O}$ losses through the control of the denitrifying community composition. In particular, the ability of the organic matter pool within the detritusphere, as influenced by translocation of organic substrates from surface decaying plant debris, to influence the composition and the activity of denitrifiers has barely been investigated in mulch-based systems. 
In this study, we aimed to investigate the impact of surface application of crop residues on soil organic matter quality, denitrifiers community composition and activity. We hypothesized that under non-limiting nitrate supply and low oxygen availability : (i) the biochemical quality of distinct decaying mulched plant materials would specifically drive soil organic matter and denitrifiers community features, (ii) the denitrification activity would be correlated to soil organic matter quality and denitrifiers community structure. Shifts in soil organic matter pool were monitored by means of near infrared reflectance spectroscopy (NIRS), evaluation of C content and ability of soil DOM to fuel denitrification. The nirK and nos $Z$ genes encoding the copper nitrite reductase and the nitrous oxide reductase were used as molecular markers of the denitrifiers community. Sequence polymorphism of amplified nirK and nos $Z$ genes fragments was revealed by means of denaturing gradient gel electrophoresis (DGGE) and restriction fragment length polymorphism (RFLP), respectively. Activity of the denitrifiers community was investigated by monitoring potential and direct $\mathrm{N}_{2} \mathrm{O}$ emissions.

\section{Materials and methods}

\section{Biological materials}

The agricultural soil was collected during dry season in the Senegal's Peanut Basin (Thyssé Kaymor) from the 0-20 cm layer in a field previously cropped with sorghum. The soil was sieved at $2 \mathrm{~mm}$, air-dried and hermetically stored at room temperature until use. It was classified as a Lixisol (FAO, 1998). Its main characteristics were : sand $55.3 \%$, loam $34.3 \%$, clay $10.4 \%, \mathrm{pH}\left(\mathrm{H}_{2} \mathrm{O}\right) 5.8$, cationic exchange capacity 5.4 meq g ${ }^{-1}$, total $\mathrm{C} 0.75 \%$ and total $\mathrm{N} 0.07 \%$. The total above-ground parts of maize (Zea mays L., $\mathrm{C} / \mathrm{N}=117$ ) and peanut (Arachis hypogaea L., $\mathrm{C} / \mathrm{N}=17$ ), both plants commonly cropped in this Senegalese region, were sampled at maturity, dried at $55^{\circ} \mathrm{C}$ for $24 \mathrm{~h}$, grinded at 2 $\mathrm{mm}$ and hermetically stored at room temperature. These plant materials displayed two distinct NIRS signatures before incubation (data not shown).

\section{Experimental design}

The microcosms consisted in $120 \mathrm{ml}$ glass flasks (diameter $5 \mathrm{~cm}$ ) containing $25 \mathrm{~g}$ equivalent dry soil that could be sealed with a rubber septum allowing headspace sampling with a needle. The height of the soil column was around $1 \mathrm{~cm}$ which encompasses the size of the detritusphere whose spatial limits have previously been estimated between 3 and $5 \mathrm{~mm}$ away from the decaying residues (Gaillard et al., 1999, Kandeler et al., 1999; Poll et al., 2006). This parameter was chosen so as to minor the volume of soil not affected by residues. Biological reactivation of the soil, collected during the dry season, and stabilisation of its respiration rate were obtained by bringing soil gravimetric water holding capacity (WHC) to $40 \%\left(+3 \mathrm{ml} \mathrm{H}_{2} \mathrm{O}\right.$ per flask) for 4 weeks at $28^{\circ} \mathrm{C}$ before adding crop residues. $\mathrm{CO}_{2}$ emissions were daily measured on 10 flasks initially chosen at random. Soil respiration was stabilized around $0.4 \mu \mathrm{g} \mathrm{CO}_{2}-\mathrm{C} \mathrm{g}^{-}$ ${ }^{1} \mathrm{~h}^{-1}$ after 14 days of incubation. Soil WHC was then raised to $70 \%$ by adding $2.25 \mathrm{ml}$ of a $0.2 \mathrm{M} \mathrm{KNO}_{3}$ solution to all microcosms to ensure soil conditions conducive for denitrification (sub-oxic conditions, non-limiting nitrate supply). Three treatments $(n=4$ replicates) were then applied on these soils supplemented with nitrate: control soil without mulch, soil covered by a maize mulch and soil covered by a peanut mulch. Maize and peanut residues were equally humidified with sterile distilled water and 
applied onto the soil surface at a rate of $900 \mathrm{mg} \mathrm{C}$ per microcosm (ca. $1 \mathrm{t}$ residue ha ${ }^{-1}$ ). All microcosms were then assigned a reference weight and further incubated opened in a randomized design in the dark at $28^{\circ} \mathrm{C}$ for five weeks. Microcosm moisture was checked three times a week on a weight basis and adjusted with sterile distilled water.

\section{Soil and gases sampling procedures}

Microcosms were destructively sampled every week ( $\mathrm{n}=4$ per treatment, Fig. 1). Flasks atmosphere was renewed with several ambient air flushes and $2 \times 4 \mathrm{ml}$ of the microcosm headspace were then sampled in sterile $3 \mathrm{ml} \mathrm{Labco}{ }^{\circledR}$ vials (Labco, Buckinghamshire, UK) for determination of initial $\mathrm{CO}_{2}$ and $\mathrm{N}_{2} \mathrm{O}$ levels. Flasks were then sealed air-tight prior to a $3 \mathrm{~h}$ incubation at $28^{\circ} \mathrm{C}$ in the dark. Afterwards, flasks atmosphere was mixed by withdrawing and injecting headspace gas three times. Final $\mathrm{CO}_{2}$ content was then directly analysed and $4 \mathrm{ml}$ of the headspace were sampled in a Labco ${ }^{\circledR}$ vial for determination of final $\mathrm{N}_{2} \mathrm{O}$ level. All decaying residues were then retrieved from the flasks with tongs and spatula. Soil was homogenised with a spatula and aliquoted for the subsequent analyses.

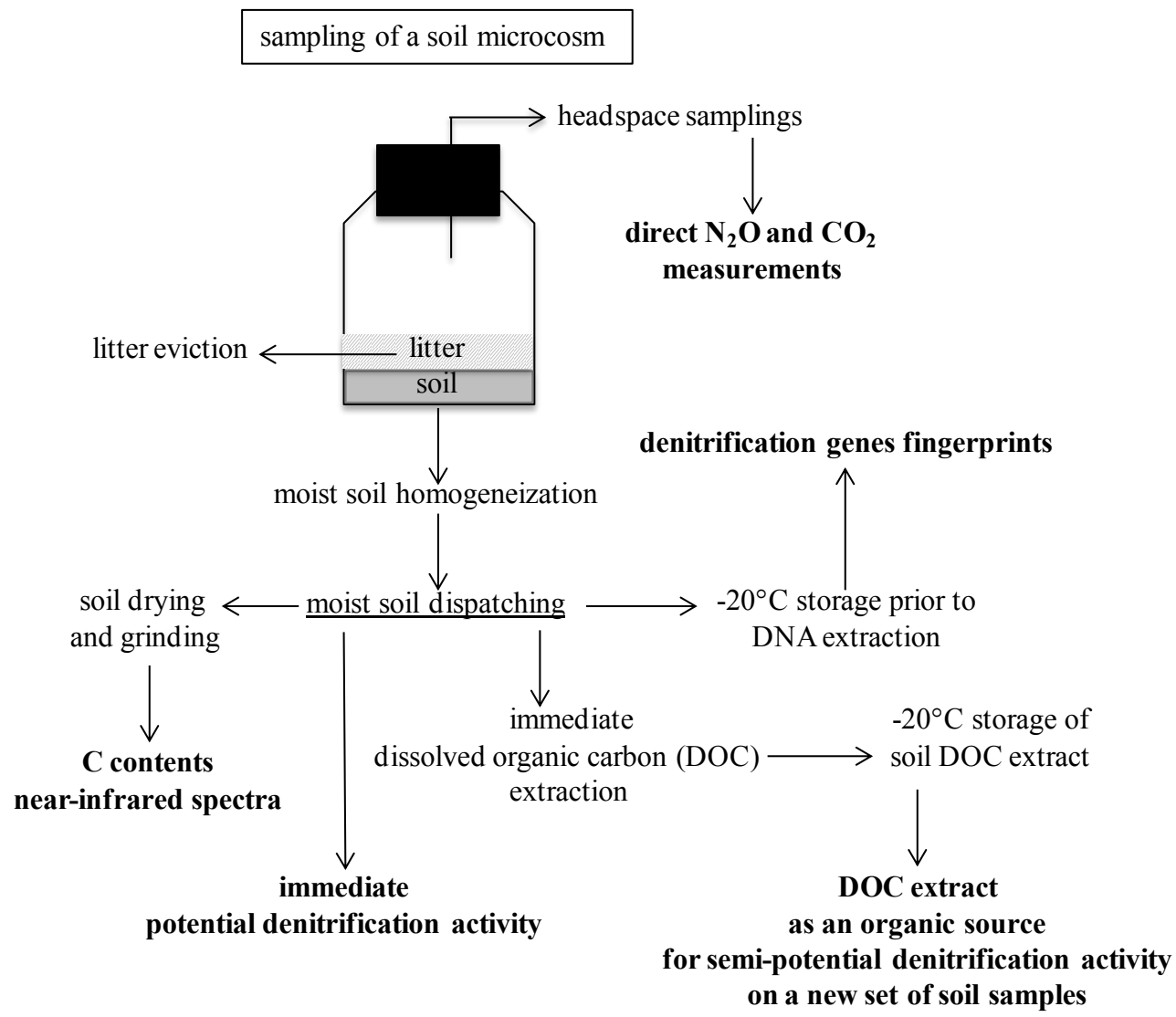

Figure 1. Analytical flowchart of a soil microcosm.

Aliquots dedicated to molecular analysis were stored at $-20^{\circ} \mathrm{C}$ before soil DNA extraction. Aliquots dedicated to $\mathrm{C}$ content and NIRS analyses were dried at $45^{\circ} \mathrm{C}$ and grinded in a mortar with a pestle. The remaining fresh soil samples were immediately processed for measurement of potential $\mathrm{N}_{2} \mathrm{O}$ emission rates and extraction of their 
DOM as follow. Moist soil (10 g equivalent dry soil) was suspended in $25 \mathrm{ml}$ distilled water and shaken for $1 \mathrm{~h}$ at room temperature on a ping-pong shaker at $100 \mathrm{rpm}$. Soil slurry was centrifuged $\left(8,000 \times g, 10 \mathrm{~min}, 4^{\circ} \mathrm{C}\right)$ and supernatant was sterilized by filtration through $0.2 \mu \mathrm{m}$ cellulose acetate Nalgene ${ }^{\circledR}$ syringe filters and stored at $-20^{\circ} \mathrm{C}$ before use. All these DOM extracts collected each week were further used simultaneously in a modified denitrification activity protocol. Hence, microbes and particulate organic matter were excluded from these solutions by $0.2 \mu \mathrm{m}$ filtration and neither additional substances (e.g. salts) nor heating were employed during the extraction process. Moreover, it is recognized that a rapid extraction at room temperature with distilled water enable an efficient recovery of soil DOM (Jones and Willett, 2006).

\section{Soil physical and chemical analyses}

Total C contents of grinded soil samples were determined by dry combustion with a CHN analyser (ThermoFinnigan Flash EA 1112 series) by US Imago (IRD, Senegal, Dakar). NIRS spectra, that characterize the diversity of covalent bonds in organic molecules, were used to fingerprint soil organic matter (Hedde et al., 2005). NIRS signatures of grinded dry soil samples packed into a quartz-glass cell were obtained between 1100 and $2500 \mathrm{~nm}$ at $2 \mathrm{~nm}$ intervals using a Foss NIRSystems 5000 spectrophotometer (Silver Spring, MD, USA). The data sets were averaged every five consecutive spectral points yielding 140 data points per spectrum. Spectra were processed using second derivatives and a standard normal variate transform with detrending (Brunet et al., 2007).

\section{Direct $\mathrm{N2O}$ and $\mathrm{CO} 2$ levels in the microcosm atmosphere}

Gas samples stored in Labco ${ }^{\circledR}$ vials were analysed for $\mathrm{N}_{2} \mathrm{O}$ with a gas chromatograph fitted with an electron capture detector (CP-3800 Varian, Les Ulis, France). Column and detector temperatures were 100 and $300^{\circ} \mathrm{C}$, respectively. Chromatograms were integrated by using Station Star 5.52 software (Varian). Net direct $\mathrm{N}_{2} \mathrm{O}$ emissions over the $3 \mathrm{~h}$ incubation period were calculated by subtracting $\mathrm{N}_{2} \mathrm{O}$ values obtained for initial ambient air to that of microcosms at the end of incubation. $\mathrm{CO}_{2}$ values were obtained with a gas chromatograph fitted with a thermal conductivity detector (P200 MTI Analytical Instruments) at the start (from gas samples in Labco ${ }^{\circledR}$ vials) and at the end of the $3 \mathrm{~h}$ incubation (directly from the microcosm headspace). A similar calculation as for $\mathrm{N}_{2} \mathrm{O}$ was applied to evaluate net direct $\mathrm{CO}_{2}$ emissions.

\section{DNA extraction and molecular fingerprints}

Three out of four microcosm replicates per treatment were randomly chosen for molecular analyses. Total soil DNA was extracted using the method described by Ndour et al., (2008). Triplicate DNA extracts (from three $500 \mathrm{mg}$ equivalent dry soil) were pooled for each microcosm, purified using the Wizard ${ }^{\circledR}$ DNA Clean-Up kit (Promega, Charbonnières, France) and quantified by agarose (2\%) electrophoresis with a calibration curve based on serial dilutions of a calf thymus DNA standard. For all denitrification genes, PCR reactions were performed with a GeneAmp PCR System 9700 (Applied Biosystems, Courtaboeuf, France) in $25 \mu 1$ mixtures elaborated with the HotStarTaq ${ }^{\circledR}$ Master Mix Kit (Qiagen, Courtaboeuf, France) and containing $10 \mathrm{ng}$ 
of template DNA. To ensure the DGGE segregation of nirK and nirS amplicons, a 33 bp GC-clamp was added to the $5^{\prime}$ end of the reverse primer. Primer pairs F1aCU/R3Cu-clamp for nirK gene, cd3aF/R3cd-clamp for nirS gene and nosZF/nosZ-R for nosZ gene were used at $1 \mu \mathrm{M}$ (Throbäck et al., 2004). Bovine serum albumin (Promega) was added to the reaction mixture at a rate of 600 and $1000 \mathrm{ng} \mu \mathrm{l}^{-1}$ PCR for nirK/nosZ and nirS genes, respectively. Thermal profiles were similar to that of Throbäck et al., (2004) with slight modifications. The initial denaturation step was set at $95^{\circ} \mathrm{C}$ for $15 \mathrm{~min}$ to activate the DNA polymerase and annealing temperatures were 53 and $58^{\circ} \mathrm{C}$ for nosZ and nirK/nirS primers, respectively. Specificity of PCR products was checked by agarose $(2 \%)$ gel electrophoresis and ethidium bromide staining. All PCR amplifications were done in duplicate, pooled and further purified with the MinElute ${ }^{\circledR}$ PCR purification Kit (Qiagen) only in the case of the DGGE analysis. The nirS gene could not be detected in any sample in contrast to the nirK and nos $Z$ genes which displayed enhanced amplification rates in amended treatments. Amplicons obtained for the nirK gene were resolved by DGGE using $8 \%$ acrylamide gels and a gradient of $45-70 \%$ denaturant (Djigal et al., 2010). Agarose slices containing pooled nosZ amplicons were processed with the Wizard ${ }^{\circledR}$ SV Gel Clean-Up System (Promega). Retrieved nosZ amplicons were quantified by agarose (2\%) gel electrophoresis and $100 \mathrm{ng}$ of purified PCR products were then digested with AluI at $37^{\circ} \mathrm{C}$ for $2 \mathrm{~h}$ (Mounier et al., 2004). Restriction fragments were then resolved by electrophoresis on 6\% acrylamide gels (acrylamide-bisacrylamide 40\%, 29:1, SigmaAldrich, Saint-Quentin Fallavier, France) at room temperature in $1 \times$ TBE buffer for 7 $\mathrm{h}$ at $90 \mathrm{~V}-17 \mathrm{~mA}$ to generate RFLP patterns. Staining of the DGGE and RFLP gels was performed with $0.5 \times \mathrm{SYBR}^{\circledR}$ Green I (Invitrogen, Cergy Pontoise, France). Scanning was described elsewhere (Ndour et al., 2008).

\section{Denitrification activity measurements}

Potential $\mathrm{N}_{2} \mathrm{O}$ accumulation in presence of acetylene was determined on moist soil (5 g equivalent dry soil) immediately after microcosm sampling in sterilized $60 \mathrm{ml}$ flasks. Flasks were sealed with a rubber septum, vacuumed for $1 \mathrm{~min}$ and flushed with He for 1 min. Soil samples were then enriched with $5 \mathrm{ml}$ of a $0.2 \mu \mathrm{m}$-filtered and degassed substrate solution containing $\mathrm{KNO}_{3}\left(0.25 \mathrm{mg} \mathrm{N} \mathrm{g}^{-1}\right.$ dry soil), glucose $\left(1 \mathrm{mg} \mathrm{C} \mathrm{g}^{-1}\right.$ dry soil) and succinate $\left(1 \mathrm{mg} \mathrm{C} \mathrm{g}^{-1}\right.$ dry soil). Ten per cent (vol/vol) of the headspace volume was replaced with an equivalent volume of acetylene to inhibit $\mathrm{N}_{2} \mathrm{O}$ reductase activity. Soil slurries were incubated at $100 \mathrm{rpm}$ and $28^{\circ} \mathrm{C}$ on an horizontal shaker. $\mathrm{N}_{2} \mathrm{O}$ concentrations were monitored with the P200 gas chromatograph along a $24 \mathrm{~h}$ incubation period.

The ability of the soil DOM, as qualitatively and quantitatively influenced by decaying residues, to fuel denitrification (semi-potential denitrification assay) was tested on $5 \mathrm{~g}$ equivalent dry soil contained in flask. The soil used for this purpose originated from the initial stock but in no case from the microcosms used for testing crop residues. Hence, its chemical and microbial properties were identical between all DOM treatments. Prior to DOM spiking, it was incubated at $40 \% \mathrm{WHC}$ and $28^{\circ} \mathrm{C}$ in 60 $\mathrm{ml}$ flasks for four weeks to lower the potential interference of autochtonous soil organic matter with the DOM assay. In this background, any DOM extract originating from a microcosm replicate of the mineralisation kinetics was individually associated to a single DOM flask replicate $(n=4)$. All frozen DOM extracts, collected from control, maize and peanut microcosms, were thawed and applied together on soil flasks. They 
were subjected to the same procedure as for the above-mentioned potential denitrification activity protocol but the glucose-succinate mixture was alternatively replaced by $5 \mathrm{ml}$ of the soil DOM extract. Each DOM extract was mixed with $250 \mu \mathrm{l}$ of a sterile $\mathrm{KNO}_{3}$ solution so as to bring $0.25 \mathrm{mg} \mathrm{N} \mathrm{g}^{-1}$ dry soil. Lastly, four additional soil flasks were processed according to the regular denitrification activity protocol in order to compare $\mathrm{N}_{2} \mathrm{O}$ accumulation under non-limiting $\mathrm{C}$ supply (i.e. glucose-succinate) to that obtained with DOM solutions.

\section{Statistical analyses}

Comparisons of $\mathrm{C}$ contents, $\mathrm{CO}_{2}$ and $\mathrm{N}_{2} \mathrm{O}$ emission rates were performed using the Tukey test $(\alpha=0.05)$ in XLSTAT (v2012.6.02, Addinsoft ${ }^{\mathrm{TM}}$, Paris, France). Data were tested for normality and log-transformed before statistical analysis when necessary. Soil initial state (Day 0) refers to microcosms sampled right after the four-week preincubation step at WHC 40\%. DGGE and RFLP fingerprints were encoded in matrices related to the presence-absence of bands and their proportional intensities using TotalLab TL120 software (Nonlinear Dynamics, Newcastle upon Tyne, UK). Similarity of encoded fingerprints and NIRS signatures was assessed by hierarchical cluster analysis (dissimilarity matrix, Euclidian distances, Ward aggregation method) in XLSTAT. Relationships between the denitrification activity levels $\left(\mathrm{N}_{2} \mathrm{O}\right.$ accumulation in presence of acetylene) and the nirK community composition, or the soil organic matter quality, were evaluated by linear regressions between $\mathrm{N}_{2} \mathrm{O}$ emission rates and principal component analysis ordinations (PCA) of DGGE fingerprints or NIRS signatures in XLSTAT (Rich et al., 2003; Rich and Myrold, 2004). Lastly, co-inertia analyses were performed to test the correlations between the molecular fingerprint and the NIRS data sets by using the ADE-4 software (Thioulouse et al., 1997).

\section{Results}

\section{Soil chemical properties}

Soil C content was lowered from 0.75 to $0.55 \%$ at the end of the pre-incubation period and was significantly increased in presence of mulched residues as soon as the first week and during the entire incubation by comparison with the control soil (data not shown). Values for control, maize and peanut treatments ranged from 0.46 to $0.53 \%$, from 0.52 to $0.72 \%$ and from 0.72 to $0.75 \%$ during the mineralisation kinetics, respectively. No significant differences were noticed between organic treatments at any time. $\mathrm{C}$ contents in amended soils were constant throughout incubation (except at the last sampling with a lower $\mathrm{C}$ content under maize mulch $(0.52 \%)$ similar to that of the control).

Soil NIRS signatures as influenced by peanut residues were completely segregated from soil spectra measured for the control and maize treatments (Fig. 2). Surprisingly, NIRS signatures associated with the soil amended with maize residues displayed strong similarities with that of the unamended soil. Nevertheless, the dendrogram branches representative of maize treatment spectra formed two sub-clusters that were distinct from that of control spectra. For all treatments, the topology of the branches associated with the 5 consecutive sampling dates was inconsistent with a chronological distribution pattern. Moreover, discrimination of spectral signatures associated with two contiguous decay stages was not systematically observed. 


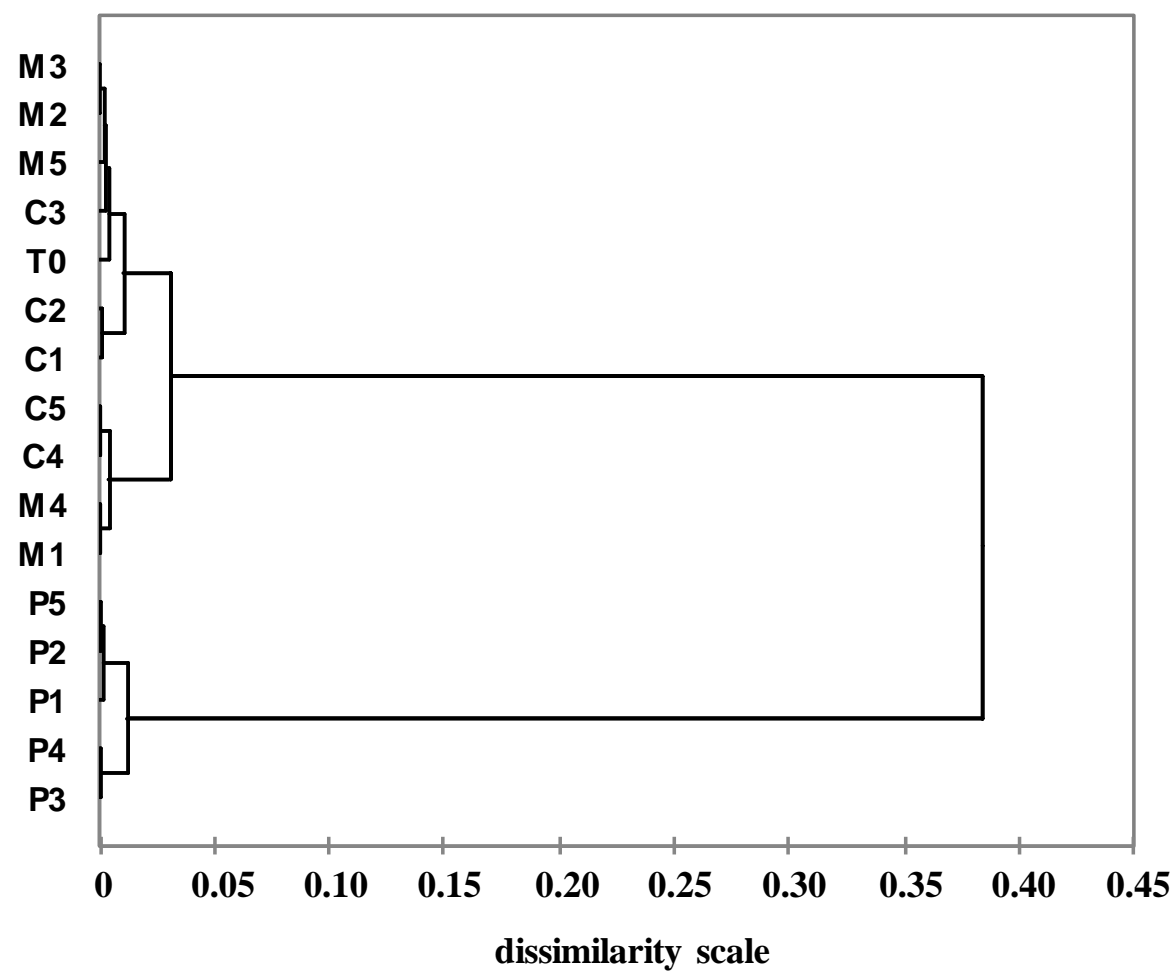

Figure 2. Impact of mulch type and decay stage on soil NIRS signatures compared by hierarchical cluster analysis. Owing to the size of the dendrogram obtained with the complete set of data (64 branches), replicate spectra were averaged $(n=4)$ before analysis. $C$ : control ; $M$ : soil under maize mulch; $P$ : soil peanut mulch ; 1-5 : week 1-week 5 ; T0 : initial state.

\section{Direct $\mathrm{CO} 2$ and $\mathrm{N} 2 \mathrm{O}$ emissions}

Respiration rates of unamended soils varied little throughout incubation (from 0.11 to $0.28 \mathrm{mg} \mathrm{CO}_{2}-\mathrm{C} \mathrm{kg}^{-1}$ dry soil $\mathrm{h}^{-1}$ ) and were significantly lower than those of residue enriched soils (Table 1). $\mathrm{CO}_{2}$ emission rates from organic treatments were residue specific at all times, except at week 2 . The respiration profile of the peanut treatment followed a declining trend (from 6.35 to $1.66 \mathrm{mg} \mathrm{CO}_{2}-\mathrm{C} \mathrm{kg}^{-1}$ dry soil h${ }^{-1}$ ), while $\mathrm{CO}_{2}$ emissions under maize peaked at the third sampling (from 2.40 to $4.53 \mathrm{mg} \mathrm{CO}_{2}-\mathrm{C} \mathrm{kg}^{-1}$ dry soil $\mathrm{h}^{-1}$ ) and declined thereafter to $3.36 \mathrm{mg} \mathrm{CO}_{2}-\mathrm{C} \mathrm{kg}^{-1}$ dry soil $\mathrm{h}^{-1}$. The highest levels were recorded in peanut microcosms during the first two weeks but from the third week, they were associated with maize microcosms.

The highest direct $\mathrm{N}_{2} \mathrm{O}$ emission rates were systematically associated with the maize treatment, especially at the first week with an average peak value of $41 \mu \mathrm{g} \mathrm{N} \mathrm{N}_{2} \mathrm{O}-\mathrm{N} \mathrm{kg}^{-1}$ dry soil $\mathrm{h}^{-1}$ (Table 1), but variation among these particular maize microcosms was high. From the second week, direct $\mathrm{N}_{2} \mathrm{O}$ emissions in maize microcosms abruptly decreased and ranged from 5.23 to $2.00 \mu \mathrm{g} \mathrm{N}_{2} \mathrm{O}-\mathrm{N} \mathrm{kg}^{-1}$ dry soil h${ }^{-1}$ while the rates estimated for the control and peanut treatments fluctuated from 1.15 to $1.53 \mu \mathrm{g} \mathrm{N}_{2} \mathrm{O}-\mathrm{N} \mathrm{kg}^{-1}$ dry soil h ${ }^{1}$. Emission rates were similar between control and peanut microcosms and close to that of bare soil just before mulches were applied (soil initial state). Owing to the size and shape of microcosms, the $5.23 \mu \mathrm{g} \mathrm{N}_{2} \mathrm{O}-\mathrm{N} \mathrm{kg}^{-1}$ dry soil h${ }^{-1}$ rate for instance would correspond to ca. $0.67 \mathrm{~g} \mathrm{~N}_{2} \mathrm{O}-\mathrm{N} \mathrm{ha}^{-1} \mathrm{~h}^{-1}$. 
Table 1. Direct $\mathrm{N} 2 \mathrm{O}$ and CO2 emission rates as influenced by mulch type and decay stage (mean value $\pm S E, n=4$ ).Different capital index letters within a column indicate significant differences $(P<0.05)$ between mulch treatments for a given gas, at a given sampling date. Different lowercase index letters within a column indicate significant differences $(P<0.05)$ between sampling dates for a given gas and a given mulch treatment.)

\begin{tabular}{|c|c|c|c|}
\hline Sampling date & Treatment & $\begin{array}{c}\text { Direct } \mathrm{N}_{2} \mathrm{O} \text { emissions } \\
\left.\left(\mathrm{N}_{2} \mathrm{O}-\mathrm{N} \mathrm{kg}^{-1} \text { dry soil h}\right)^{-1}\right) \\
\end{array}$ & $\begin{array}{c}\text { Direct } \mathrm{CO}_{2} \text { emissions } \\
\left.\left(\mathrm{mg} \mathrm{CO}_{2}-\mathrm{C} \mathrm{kg}^{-1} \text { dry soil h}\right)^{-1}\right)\end{array}$ \\
\hline Day 0 & Initial state & $1.24 \pm 0.08$ & $0.09 \pm 0.01$ \\
\hline \multirow{3}{*}{ Week 1} & Control & $1.23 \pm 0.06^{\mathrm{A}, \mathrm{a}}$ & $0.15 \pm 0.01^{\mathrm{C}, \mathrm{a}}$ \\
\hline & Peanut mulch & $1.05 \pm 0.02^{\mathrm{A}, \mathrm{a}}$ & $6.35 \pm 0.81^{\mathrm{A}, \mathrm{a}}$ \\
\hline & Maize mulch & $41.10 \pm 20.08^{\mathrm{A}, \mathrm{a}}$ & $2.40 \pm 0.29^{\mathrm{B}, \mathrm{b}}$ \\
\hline \multirow{3}{*}{ Week 2} & Control & $1.35 \pm 0.03^{\mathrm{B,a}}$ & $0.28 \pm 0.05^{\mathrm{B}, \mathrm{a}}$ \\
\hline & Peanut mulch & $1.15 \pm 0.02^{\mathrm{B}, \mathrm{a}}$ & $3.91 \pm 0.61^{\mathrm{A}, \mathrm{b}}$ \\
\hline & Maize mulch & $5.23 \pm 1.38^{\mathrm{A}, \mathrm{b}}$ & $2.56 \pm 0.07^{\mathrm{A}, \mathrm{b}}$ \\
\hline \multirow{3}{*}{ Week 3} & Control & $1.53 \pm 0.22^{\mathrm{AB}, \mathrm{a}}$ & $0.16 \pm 0.01^{\mathrm{C}, \mathrm{a}}$ \\
\hline & Peanut mulch & $1.15 \pm 0.02^{\mathrm{B}, \mathrm{a}}$ & $2.74 \pm 0.28^{\mathrm{B}, \mathrm{bc}}$ \\
\hline & Maize mulch & $2.04 \pm 0.20^{\mathrm{A}, \mathrm{b}}$ & $4.53 \pm 0.58^{\mathrm{A}, \mathrm{a}}$ \\
\hline \multirow{3}{*}{ Week 4} & Control & $1.23 \pm 0.01^{\mathrm{A}, \mathrm{a}}$ & $0.26 \pm 0.07^{\mathrm{B}, \mathrm{a}}$ \\
\hline & Peanut mulch & $1.18 \pm 0.01^{\mathrm{A}, \mathrm{a}}$ & $1.52 \pm 0.14^{\mathrm{B}, \mathrm{c}}$ \\
\hline & Maize mulch & $2.00 \pm 0.38^{\mathrm{A}, \mathrm{b}}$ & $3.64 \pm 0.56^{\mathrm{A}, \mathrm{ab}}$ \\
\hline \multirow{3}{*}{ Week 5} & Control & $1.32 \pm 0.04^{\mathrm{B}, \mathrm{a}}$ & $0.11 \pm 0.01^{\mathrm{C}, \mathrm{a}}$ \\
\hline & Peanut mulch & $1.46 \pm 0.28^{\mathrm{B}, \mathrm{a}}$ & $1.66 \pm 0.29^{\mathrm{B}, \mathrm{c}}$ \\
\hline & Maize mulch & $3.10 \pm 0.57^{\mathrm{A}, \mathrm{b}}$ & $3.36 \pm 0.14^{\mathrm{A}, \mathrm{ab}}$ \\
\hline
\end{tabular}

\section{Denitrification activity}

$\mathrm{N}_{2} \mathrm{O}$ emissions were significantly favoured in soils covered by mulched residues as compared to control soil for which no emission could be detected, except with bare soil before plant debris were applied (Fig. 3). Emission levels were residue specific at each sampling date and were the lowest under peanut residues during the first three samplings. The highest overall rate was associated with the maize treatment that induced an emission peak around $10 \mu \mathrm{g} \mathrm{N}_{2} \mathrm{O}-\mathrm{N} \mathrm{g}^{-1} \mathrm{~h}^{-1}$ at the first stage, in contrast to 3 $\mu \mathrm{g} \mathrm{N} \mathrm{N}_{2} \mathrm{O}-\mathrm{N} \mathrm{g}^{-1} \mathrm{~h}^{-1}$ in the case of the peanut treatment. As $\mathrm{N}_{2} \mathrm{O}$ emissions from control microcosms were below our detection threshold, PCA of soil NIRS signatures was only performed with spectra obtained from organic treatments. In this case, $\mathrm{N}_{2} \mathrm{O}$ emission rates were not correlated with the PCA scores of the corresponding soil NIRS signatures $\left(\mathrm{R}^{2}=0.16\right.$ and 0.11 for axis 1 and 2 , data not shown), suggesting an absence of relationship between $\mathrm{N}_{2} \mathrm{O}$ emissions and quality of soil organic matter as influenced by decaying mulches.

The soil DOM extracted from peanut microcosms triggered the highest denitrification activities whatever the sampling date, as compared to those obtained with DOM extracted from control and maize microcosms (Fig. 4). These highest scores ranged from 0.29 to $0.47 \mu \mathrm{g} \mathrm{N}_{2} \mathrm{O}-\mathrm{N} \mathrm{g} \mathrm{g}^{-1} \mathrm{~h}^{-1}$. For all treatments however, $\mathrm{N}_{2} \mathrm{O}$ emission rates were significantly inferior to that of the reference soil enriched with the glucosesuccinate solution (ca. $1.2 \mu \mathrm{g} \mathrm{N}_{2} \mathrm{O}-\mathrm{N} \mathrm{g}^{-1} \mathrm{~h}^{-1}$ ). C contents of DOM extracts could not be measured due to methodological limitations. We speculated they could be proportional 
to $\mathrm{C}$ contents of the corresponding soil samples and in this case no correlation was found between those $\mathrm{C}$ contents and $\mathrm{N}_{2} \mathrm{O}$ levels sustained by the corresponding DOM extracts (data not shown).

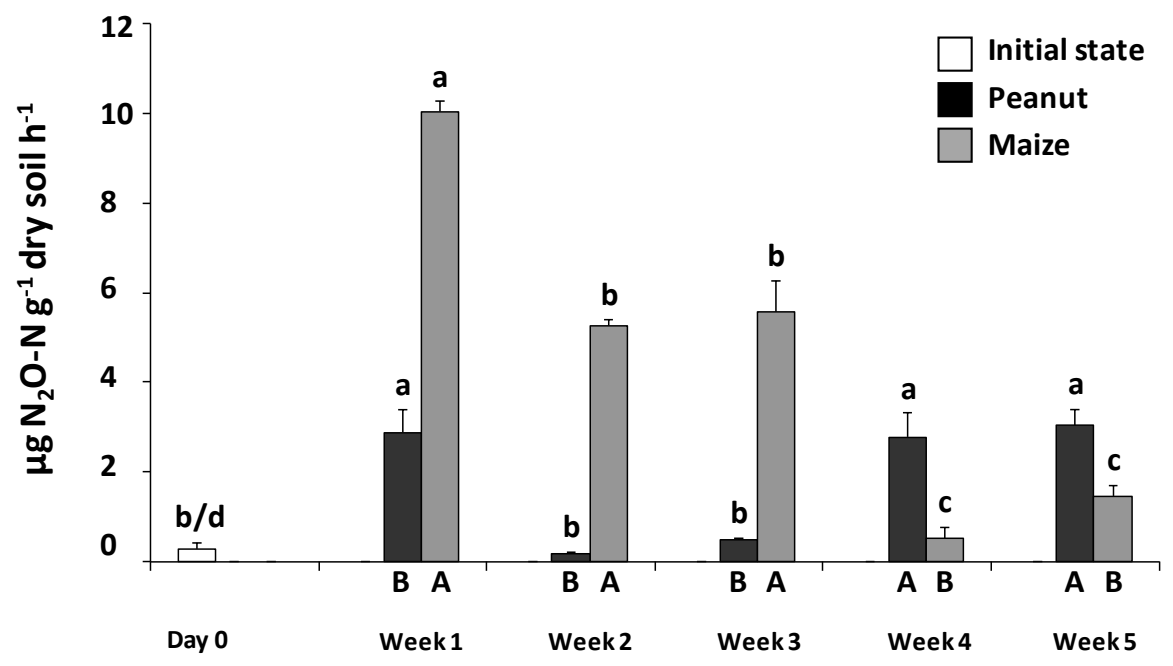

Figure 3. Soil denitrification activity as influenced by mulch type and decay stage (mean and standard error, $n=4)$. No column was drawn for the control treatment as no N2O could be detected. Different capital letters at the bottom of columns indicate significant differences $(P<$ $0.05)$ between treatments at a given sampling date. Different lowercase letters at the top of columns indicate significant differences $(P<0.05)$ between sampling dates within a given treatment. At the top of the first column (day 0 ), the two lowercase letters refer to the statistical comparisons between soil initial state and peanut / maize treatments, respectively.

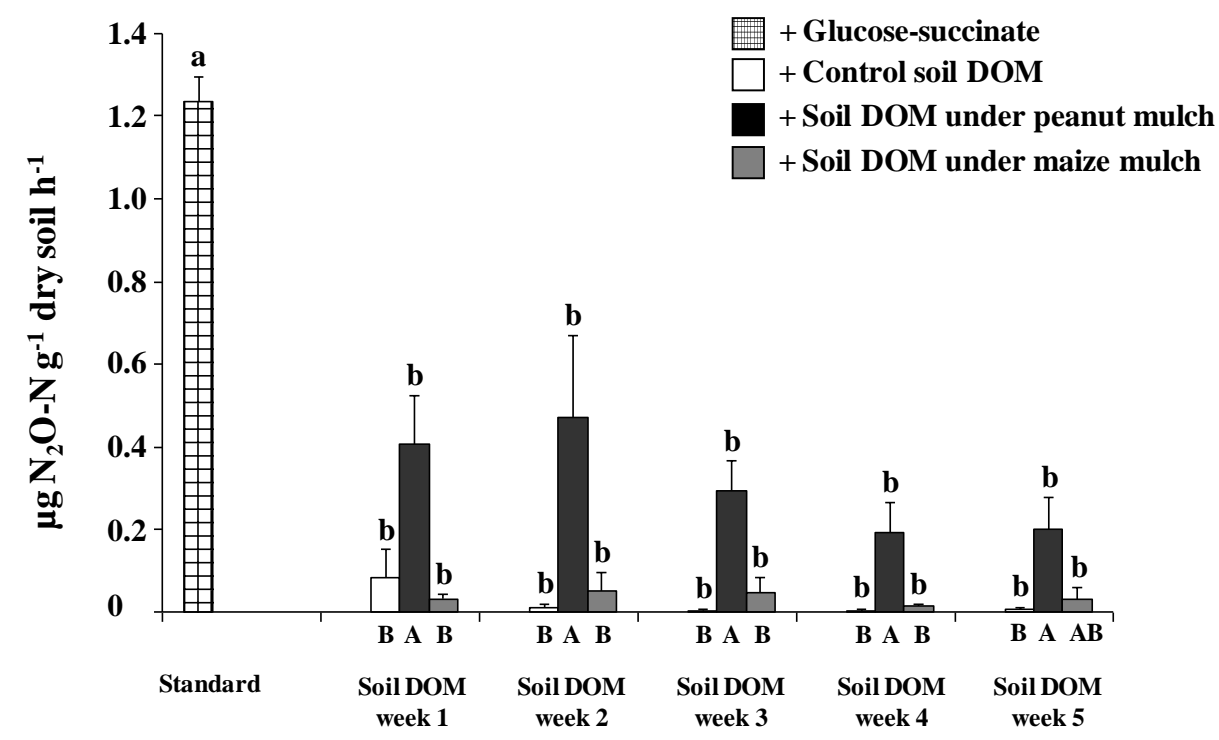

Figure 4. Denitrification activity of the reference soil as influenced by spiking with soil DOM extracted from control and mulch microcosms during the mineralization kinetics (mean and standard error, $n=4)$. The hashed column stands for soil spiking with the glucose-succinate solution (non-limiting C supply). Capital and lowercase letters hold the same signification as in Fig. 3. At the top of the first column (standard), the lowercase letter refers to the statistical comparison with all treatments. 


\section{Denitrifiers community structure}

Amplification of nirS gene fragments from soil DNA failed with all soil samples despite attempts to improve amplification parameters, especially combinations of increased amounts of template DNA, bovine serum albumine and primers, as well as lower annealing temperatures. A similar situation occurred with the nirK gene but only in the case of control soil. By contrast, nos $Z$ gene fragments could be successfully amplified from all soil samples.

The nirK gene fingerprints were not identical among replicates as observable in Fig. $5 A$. Against that background, banding patterns were segregated in two monospecific clusters corresponding to the maize and peanut treatments (Fig. 5B).

(A)

$\begin{array}{llllllllllllllll}1 & 2 & 3 & 4 & 5 & 6 & 7 & 8 & 9 & 10 & 11 & 12 & 13 & 14 & 15\end{array}$

(B)
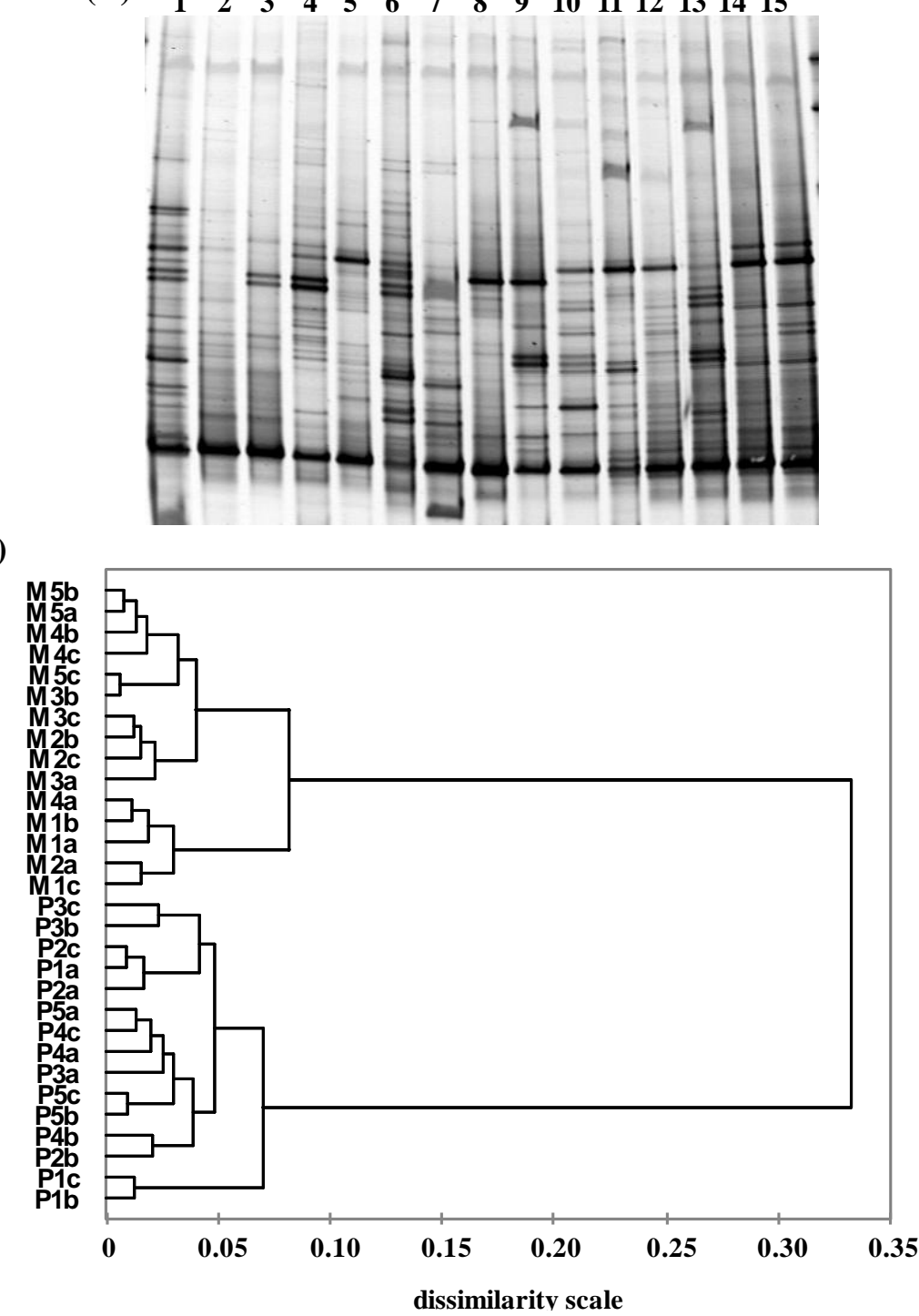

Figure 5. (A) DGGE migration profiles resolving the diversity of nirK gene fragments amplified from soil DNA of peanut microcosms $(n=3)$. Lanes 1-3: week 1, lanes 4-6: week 2, lanes 7-9: week 3, lanes 10-12: week 4, lanes 13-15: week 5. (B) Impact of mulch type and decay stage on nirK-DGGE fingerprints compared by hierarchical cluster analysis. $M$ : soil under maize mulch ; $P$ : soil peanut mulch ; $1-5$ : week 1-week 5 ; a-c : triplicate number. 
In both cases, no gradual shift of fingerprints related to the 5 consecutive sampling stages could be evidenced as the topology of each cluster did not fit a chronological distribution. $\mathrm{N}_{2} \mathrm{O}$ emission levels from maize and peanut treatments (see Fig. 3) were not correlated with PCA ordination of the corresponding nirK fingerprints $\left(\mathrm{R}^{2}=0.24\right.$ and 0.07 for axis 1 and 2, data not shown), possibly indicating a poor link between $\mathrm{N}_{2} \mathrm{O}$ production and the genetic structure of the copper nitrite reductase community. Coinertia analysis revealed that the mulch type effect on soil nirK fingerprints was highly correlated to that on soil spectral signatures $(P<0.0001)$.

The $\operatorname{nos} Z$ gene fingerprints were rather similar among triplicates as exemplified in Fig. 6A.

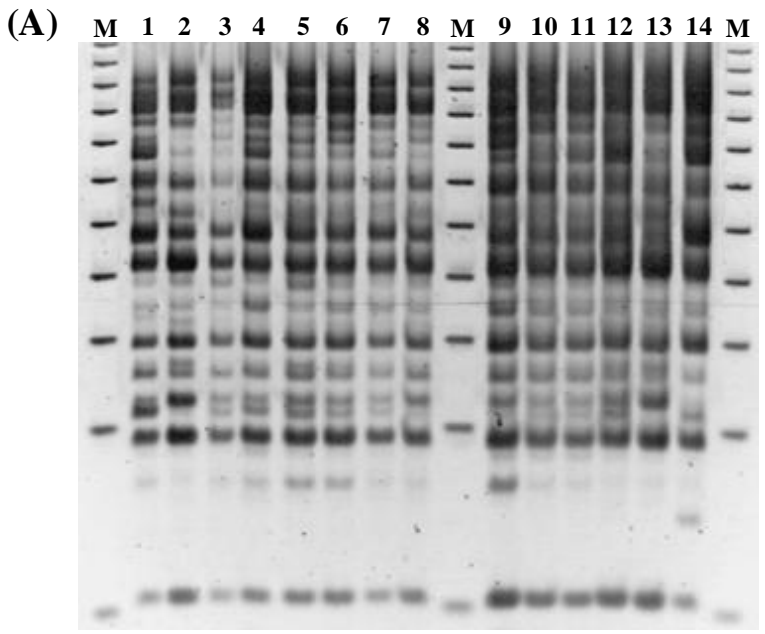

(B)

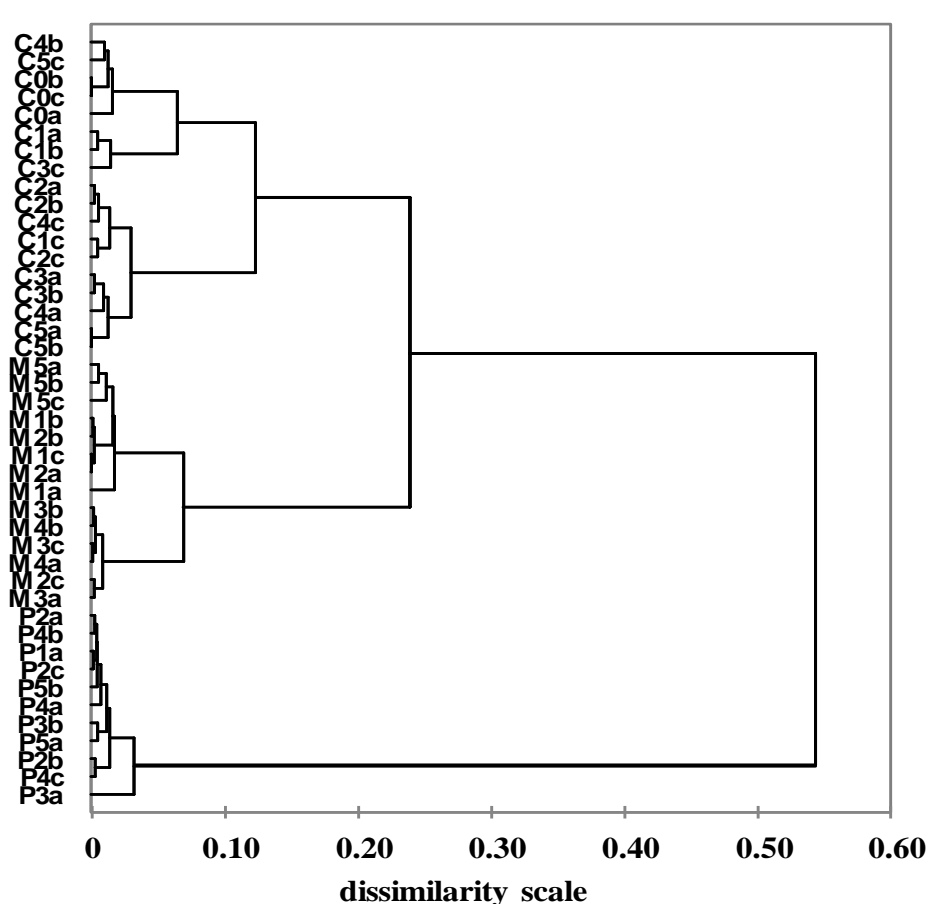

Figure 6. (A) RFLP migration profiles resolving the diversity of nos $Z$ gene fragments amplified from soil DNA of maize microcosms $(n=3)$. Lanes 1-3: week 5, lanes 4-5: week 4, lanes 6-8: week 3, lanes 9-11: week 2, lanes 12-14: week 1. M: 50 bp molecular weight marker. (B) Impact of mulch type and decay stage on nosZ-RFLP fingerprints compared by hierarchical cluster analysis. $C$ : control ; $M$ : soil under maize mulch ; $P$ : soil peanut mulch ; 0 : initial sate ; $1-5$ : week 1 -week 5 ; a-c: triplicate number. 
The genetic structure of the soil nitrous oxide reductase community also proved to be specifically driven by the type of mulched residue as indicated by the cluster analysis (Fig. 6B) : the dendrogram topology displayed 3 monospecific clusters corresponding to the 3 treatments. The peanut treatment triggered the strongest structural shifts within this denitrifiers community as its cluster was much less similar to the control cluster than that of the maize treatment. Again, distribution of intra-cluster branches related to the different sampling dates was inconsistent with a chronological pattern. Additionally and in contrast to the nirK community, temporal fluctuations of the nitrous oxide reductase community composition were very weak as indicated by the very short lengths of the dendrogram branches. Co-inertia analysis revealed that the mulch type effect on soil nos $Z$ fingerprints was highly correlated to that on soil spectral signatures $(P<0.0001)$.

\section{Discussion}

\section{Mulch effects on direct $\mathrm{N}_{2} \mathrm{O}$ emissions}

Combined organic and mineral fertilizers are known to favour soil denitrification and $\mathrm{N}_{2} \mathrm{O}$ emissions (IPCC, 2007). In particular, the amplitude of these gaseous $\mathrm{N}$ losses has been characterized as plant residue quality and placement driven. Little is known however about the ecology of the denitrifiers community in the detritusphere of mulched crop residues, especially whether soil organic matter quality and denitrifiers community composition hold a functional role in these $\mathrm{N}_{2} \mathrm{O}$ releases. Besides a strong initial $\mathrm{N}_{2} \mathrm{O}$ emission peak under maize residues, the average emission rate associated to maize treatment over the last four stages was close to $3 \mu \mathrm{g} \mathrm{N} \mathrm{N}_{2} \mathrm{O}-\mathrm{N}$ $\mathrm{kg}^{-1}$ soil $\mathrm{h}^{-1}$ (corresponding to ca. $0.38 \mathrm{~g} \mathrm{~N}^{-1} \mathrm{~h}^{-1}$ owing to the microcosm size) which was almost three times higher than that of the control and peanut treatments ( 1.3 and $1.2 \mu \mathrm{g} \mathrm{N}_{2} \mathrm{O}-\mathrm{N} \mathrm{kg}^{-1}$ soil h${ }^{-1}$, respectively or ca. $0.16 \mathrm{~g} \mathrm{~N} \mathrm{ha}^{-1} \mathrm{~h}^{-1}$ equivalent). These emission levels were far below ranges estimated from field experiments. For instance, a $2.5 \mathrm{~kg} \mathrm{~N}_{2} \mathrm{O}-\mathrm{N} \mathrm{ha}^{-1}$ loss was emitted over 23 days (namely $4.5 \mathrm{~g} \mathrm{~N}^{-1} \mathrm{~h}^{-1}$ ) in response to field application of ammonitrate fertilizer and rye residues under zero tillage (Baggs et al., 2003). Similarly, the incorporation of wheat green manure in combination with ammonitrate fertilizer led to a maximum $\mathrm{N}_{2} \mathrm{O}$ emission rate of 1.5 $\mathrm{kg} \mathrm{N}$ ha ${ }^{-1}$ over 55 days (1.1 $\mathrm{g} \mathrm{N} \mathrm{ha}^{-1} \mathrm{~h}^{-1}$ ) (Sarkodie-Addo et al., 2003). Under laboratory conditions, soil $\mathrm{N}_{2} \mathrm{O}$ emissions did not exceed $3 \mathrm{mg} \mathrm{N}_{2} \mathrm{O}-\mathrm{N} \mathrm{kg}^{-1}$ soil over $144 \mathrm{~h}$ (ca. $21 \mu \mathrm{g} \mathrm{N} \mathrm{kg}{ }^{-1}$ soil h$^{-1}$ ) in response to red clover or barley straw residues incorporation (Miller et al., 2008). The emissions detected within control microcosms were very likely associated with further consumption of the native soil organic $\mathrm{C}$ that was favoured by the initial nitrate supply. $\mathrm{N}_{2} \mathrm{O}$ emission from bare soil was also noticed in other studies using mineral $\mathrm{N}$ fertilizers (Seneviratne et al., 1998; Miller et al., 2008). Here, the compositional differences between maize and peanut residues significantly impacted the direct $\mathrm{N}_{2} \mathrm{O}$ emission patterns. Unexpectedly, the highest losses were not associated to the $\mathrm{N}$ rich peanut residues. This result contrasted with most studies reporting that the largest increases in direct $\mathrm{N}_{2} \mathrm{O}$ emissions were obtained with low C/N plant debris (Larsson et al., 1998; Velthof et al., 2002; Huang et al., 2004). Here, the poor $\mathrm{N}$ content of maize residues was probably counterbalanced by the initial nitrate supply that provided enough mineral $\mathrm{N}$ to efficiently mineralize these residues (Jingguo and Bakken, 1997; Cheshire et al., 1999), leading to the buildup of a reducing power involved in denitrification of the excess nitrate. As differences 
in $\mathrm{N}_{2} \mathrm{O}$ losses between control and mulch treatments were salient when measured in presence of acetylene but faint when directly measured in the microcosm atmosphere, it can be postulated that the $\mathrm{N}_{2} \mathrm{O}$ reductase activity was also favoured in mulch microcosms leading to direct $\mathrm{N}_{2} \mathrm{O}$ losses close to those of the control. Unfortunately, the denitrification activity protocol was not performed in the absence of acetylene which prevented us from estimating the soil $\mathrm{N}_{2} \mathrm{O}$ reductase activity. However, the increased PCR rates registered for nos $Z$ gene in organic treatments could indirectly indicate that this community was also stimulated, and in turn that all denitrification steps were favoured by the residues application. The $\mathrm{N}_{2} \mathrm{O}$ reductase activity could also have been directly favoured whithin mulches as already observed with mulched tree leaves and rice debris (Seneviratne et al., 1998). Here at all samplings and mostly with peanut residues, we additionally observed a strong $\mathrm{N}_{2} \mathrm{O}$ reductase activity within decaying mulches that were enriched with a glucose-succinate solution and incubated in presence of $0.3 \%$ exogenous $\mathrm{N}_{2} \mathrm{O}$ that was completely converted to $\mathrm{N}_{2}$ within 22 hours (personal data). Interestingly, the result from this complementary observation is in line with the lower direct $\mathrm{N}_{2} \mathrm{O}$ values measured in peanut microcosms as compared to maize ones (Table 1). Moreover, the strongest alterations of the genetic structure of the nos $Z$ community occurred in soil under peanut residues.

\section{Mulch effects on the denitrifiers community}

The soil denitrification activity increased and the denitrifiers community composition shifted in response to soil amendment with plant materials as compared to unamended soil. Moreover, the extent of these effects varied according to the quality of mulched residues and the incubation stage. Field manipulations of mineral and organic inputs were also shown to impact on these denitrifiers community traits, as exemplified with sewage sludge (Enwall et al., 2005) and composted pig manure (Dambreville et al., 2006) on narG and nos $Z$ genes diversity. In other ecosystem types or in soil microcosms, denitrifiers were also susceptible to the variation in organic substrates availability and diversity (Hallin et al., 2006; Dodla et al., 2008; Gibert et al., 2008; Henderson et al., 2010). Here, the compositional shifts that affected the nitrite and the nitrous oxide reductase communities in amended soils were community specific in so far as the different clusters and sub-clusters of both dendrograms (see Figs. 5B and 6B) did not gather the same experimental units. Additionally, the dissimilarity levels between samples of a given mulch treatment were more pronounced within the nirK community. In line with this observation, some studies have also pointed out that the nirK, nirS and nosZ genes density or diversity could be differently impacted by disturbances like simple and complex substrates addition (Hallin et al., 2006; Henderson et al., 2010), cattle grazing (Philippot et al., 2009) or soil restoration (Smith and Ogram, 2008). This has been attributed to a niche differentiation between the nirK and nirS denitrifiers (Hallin et al., 2006; Philippot et al., 2009; Braker et al., 2012). Our data suggest that such a niche differentiation among denitrifiers is physically possible within the detritusphere that is known to house a sharp gradient of biotic and abiotic factors (Gaillard et al., 1999; Kandeler et al., 1999). In this background, our denitrification activity values and nirK gene profiles did not evolve in the same way. Functional attributes of the denitrifiers community composition have already been investigated in various ecosystems as exemplified recently in rhizosphere (Hamonts et al., 2013), earthworm guts (Depkat-Jakob et al., 2013) or casts (Giannopoulos et al., 2011; Majeed et al., 2013) environments. While positive relationships between nos $Z$ gene diversity 
and denitrification rates were evidenced in forest soils (Rich et al., 2003) and in a wetland mitigation bank (Peralta et al., 2010), most of the time no such correlation could be detected with the nosZ gene in soil (Mounier et al., 2004; Rich and Myrold, 2004; Enwall et al., 2005; Boyle et al., 2006), the nirS gene in a salt marsh (Cao et al., 2008) and the nirK gene in soil (Wertz et al., 2009). More recently, the composition and the abundance of the nirK, nirS and nos $Z$ denitrification genes were clearly connected to functional differences (i.e. ex situ $\mathrm{N}_{2} \mathrm{O} / \mathrm{N}_{2}$ ratios) of contrasting organic soils (Braker et al., 2012). These opposite conclusions could mean that the strength of the link between denitrifiers diversity and denitrification rate is ecosystem specific, depending on local selection processes driven by long-term variations in environmental factors. The degree to which the denitrification activity is mainly governed by the denitrifiers diversity may also vary along the year, given that environmental parameters and denitrifiers community attributes are subjected to seasonal variation (Wolsing and Priémé, 2004; Dandie et al., 2008; McGill et al., 2010). It has been suggested that denitrifiers density rather than diversity could better correlate with this process rate (Baudoin et al., 2009; Hallin et al., 2009). Yet in several studies, no or poor correlations between denitrifiers density and activity were observed (Čuel et al., 2010; Dandie et al., 2008; Miller et al., 2008). A possible limitation of using both approaches independently is that overall activity could result from the interaction between density and composition of the denitrifiers community as overall activity can be regarded as the combination of all activities per cell unit that probably vary from one denitrifier to the next owing to a wide range of sensitivity to abiotic factors (e.g. oxygen, $\mathrm{pH}$, temperature), even between closely related strains (Chèneby et al., 2000; Jones et al., 2011). Other methodological considerations restricting data interpretation were discussed by Philippot and Hallin (2005). Eventually, the recurrent difficulty to correlate denitrification activity to denitrifiers community structure could stem from methodological bottlenecks that are still limiting a routine identification of denitrifiers actively contributing to $\mathrm{N}_{2} \mathrm{O}$ emissions. Indeed, it is not possible to confirm that all PCR detected marker genes, as depicted in DNA-based fingerprints, are expressed during the denitrification assay or during in situ gas sampling, as evidenced along a comparison of DNA and cDNAderived banding patterns targeting the nirK and nirS genes (Sharma et al., 2006). However, Wertz et al. (2009) failed to evidence a strong link between denitrification activity and community composition of the active nirK denitrifiers determined by DGGE of nirK transcripts in an agricultural soil. In our case, the genetic structure of the nirS community, which was probably involved in the $\mathrm{N}_{2} \mathrm{O}$ emissions, could not be determined and integrated in the functional study of the nitrite reducer community. Such unsatisfactory amplification of the nirS gene has also been reported in several publications using the same primers set (Dandie et al., 2008) or a distinct one (Sharma et al., 2005).

\section{Mulch effects on soil organic matter}

Besides its capacity to quantitatively predict soil or litter chemical properties such as C-N-P contents, the NIRS technique has also been shown to be sensitive enough to sort soils according to their origins on the basis of qualitative comparisons of their spectral fingerprints (Hedde et al., 2005; Velasquez et al., 2005; Chapuis-Lardy et al., 2010). Here, NIRS was also a valuable tool to discriminate soils according to their mulch cover thus highlighting its usefulness to fingerprint soil organic matter quality. Soil spectral signatures and denitrification activity were both highly susceptible to the 
biochemical quality of mulched residues and their decay stages but no correlation was found between both variables suggesting that the extent of $\mathrm{N}_{2} \mathrm{O}$ emissions was uncoupled to the dynamics of soil organic matter quality. The soil DOM, as influenced by surface decaying plant debris, proved to act as a relevant electrons donor for denitrifiers and its functional value was dependant on the residue type. It is generally recognised that the more DOM is available, the more $\mathrm{N}_{2} \mathrm{O}$ is produced (Burford and Bremner, 1975; Murray et al., 2004). Most of the substrates readily available for microorganisms are very likely to be released from plant debris into the soil solution at early decay stages which is congruent here with the strongest $\mathrm{N}_{2} \mathrm{O}$ scores recorded when using DOM extracts collected under peanut residues during the first three weeks of their mineralisation. DOM-induced $\mathrm{N}_{2} \mathrm{O}$ emissions can also be inflected by the chemical composition of the soil DOM (e.g. C/N ratio) as exemplified with agroforestry residues (Millar and Baggs, 2005). However with DOM originating from maize microcosms, $\mathrm{N}_{2} \mathrm{O}$ emissions could not be differentiated from that of the control. If one assume that DOM is proportional to the total soil $\mathrm{C}$ content, this result contradicts the similar soil $\mathrm{C}$ contents observed between organic treatments that were higher than those measured in control soil. Possibly, soluble compounds released by peanut residues were more easily assimilable than those collected under maize residues. Moreover, it cannot be excluded that mineralization of maize residues generated more microparticles (size $>0.45 \mu \mathrm{m}$ ) than the peanut mulch that were located in the soil poral network but discarded from this denitrification assay by the $0.2 \mu \mathrm{m}$ filtration, resulting in less concentrated soil extracts. Such a preponderant effect of DOM concentration over DOM quality was observed on mineralization and microbial biomass with different types of forest stands (Smolander and Kitunen, 2002). Overall, as $\mathrm{N}_{2} \mathrm{O}$ production sustained by all soil extracts were several folds inferior to that obtained with the glucose-succinate solution, organic load of these DOM extracts was a limiting factor for denitrification in this assay.

\section{Conclusions}

This study evidenced that the original biochemical quality of mulched residues is potentially a strong driver of the temporal patterns of soil organic matter quality, composition and activity of the denitrifiers community inhabiting the detritusphere. In particular, the quality of the mulched residue was shown to condition the ability of the soil DOM sampled from the soil-litter interface to fuel the $\mathrm{N}_{2} \mathrm{O}$ production. Modifications of the nirK and nosZ community structure were shown to be correlated to the evolution of the soil organic matter quality during the residue decomposition. Against that background and in line with other reports encompassing diverse agroecosystems, our results highlighted however that neither changes in the denitrifiers community composition nor in the soil organic matter were coupled to the denitrification activity pattern during the decomposition of plant debris. These data also suggested the importance to integrate the denitrifiers community within the mulched residues in addition to that of the detritusphere when microbiological determinants of $\mathrm{N}_{2} \mathrm{O}$ emissions of mulch-based systems are to be studied.

Ackowledgements. This work was funded by the French National Program ACI-FNS Continental Ecosphere "ECCO-2004". 


\section{REFERENCES}

[1] Baggs, E.M., Millar, N., Ndufa, J.K., Cadisch, G. (2001): Effect of residue quality on $\mathrm{N}_{2} \mathrm{O}$ emissions from tropical soils. - In: Rees, R.M., Ball, B.C., Campbell, C.D., Watson, C.A., (Eds.), Sustainable Management of Soil Organic Matter. CAB International, Edinburgh. pp. 120-125.

[2] Baggs, E.M., Stevenson, M., Pihlatie, M., Regar, A., Cook, H., Cadish G. (2003): Nitrous oxide emissions following application of residues and fertiliser under zero and conventional tillage. - Plant Soil 254: 361-370.

[3] Bateman, E.J., Baggs, E.M. (2005): Contributions of nitrification and denitrification to $\mathrm{N}_{2} \mathrm{O}$ emissions from soils at different water-filled pore space. - Biology and Fertility of Soils 41: 379-388.

[4] Baudoin, E., Philippot, L., Chèneby, D., Chapuis-Lardy, L., Fromin, N., Bru, D., Rabary, B., Brauman, A. (2009): Direct seeding mulch-based cropping increases both the activity and the abundance of denitrifier communities in a tropical soil. - Soil Biology and Biochemistry 41: 1703-1709.

[5] Bouwman, A.F. (1998): Nitrogen oxides and tropical agriculture. - Nature 392: 866-867.

[6] Boyle, S.A., Rich, J.J., Bottomley, P.J., Cromack, K., Myrold, D.D. (2006): Reciprocal transfer effects on denitrifying community composition and activity at forest and meadow sites in the Cascade Mountains of Oregon. - Soil Biology and Biochemistry 38: 870-878.

[7] Braker, G., Dörsch, P., Bakken, L.R. (2012): Genetic characterization of denitrifier communities with contrasting intrinsic functional traits. - FEMS Microbiology Ecology 79: 542-554.

[8] Brunet, D., Barthès, B., Chotte, J.L., Feller, C. (2007): Determination of carbon and nitrogen contents in Alfisols, Oxisols and Ultisols from Africa and Brazil using NIRS analysis : effects of sample grinding and set heterogeneity. - Geoderma 139: 106-117.

[9] Burford, J.R., Bremner, J.M. (1975): Relationships between the denitrification capacities of soils and total, water-soluble and readily decomposable soil organic matter. - Soil Biology and Biochemistry 7: 389-394.

[10] Cao, Y., Green, P.G., Holden, P.A. (2008): Microbial community composition and denitrifying enzyme activities in salt marsh sediments. - Applied Environmental Microbiology 74: 7585-7595.

[11] Cavigelli, M.A., Robertson, G.P. (2000): The functional significance of denitrifier community composition in a terrestrial ecosystem. - Ecology 81: 1402-1414.

[12] Cavigellli, M.A., Robertson, G.P. (2001): Role of denitrifier diversity in rates of nitrous oxide consumption in a terrestrial ecosystem. - Soil Biology and Biochemistry 33: 297310.

[13] Chantigny, M.H. (2003): Dissolved and water-extractable organic matter in soils : a review on the influence of land use and management practices. - Geoderma 113: 357-380.

[14] Chapuis-Lardy, L., Brauman, A., Bernard, L., Pablo, A.L., Toucet, J., Mano, M.J., Weber, L., Brunet, D., Razafimbelo, T., Chotte, J.L., Blanchart, E. (2010): Effect of the endogeic earthworm Pontoscolex corethrurus on the microbial structure and activity related to $\mathrm{CO}_{2}$ and $\mathrm{N}_{2} \mathrm{O}$ fluxes from a tropical soil (Madagascar). - Applied Soil Ecology 45: 201-208.

[15] Chèneby, D., Philippot, L., Hartmann, A., Hénault, C., Germon, J.C. (2000): 16S rDNA analysis for characterization of denitrifying bacteria isolated from three agricultural soils. - FEMS Microbiology Ecology 34: 121-128.

[16] Cheshire, M.V., Bedrock, C.N., Williams, B.L., Chapman, S.J., Solntseva, I., Thomsen, I. (1999): The immobilization of nitrogen by straw decomposing in soil. - European Journal of Soil Science 50: 329-341.

[17] Čuhel, J., Šimek, M., Laughlin, R.J., Bru, D., Chèneby, D., Watson, C.J., Philippot, L. (2010): Insights into the effect of soil $\mathrm{pH}$ on $\mathrm{N}_{2} \mathrm{O}$ and $\mathrm{N}_{2}$ emissions and denitrifier community size and activity. - Applied Environnmental Microbiology 76: 1870-1878. 
[18] Dambreville, C., Hallet, S., Nguyen, C., Morvan, T., Germon, J.C., Philippot, L. (2006): Structure and activity of the denitrifying community in a maize-cropped field fertilized with composted pig manure or ammonium nitrate. - FEMS Microbiology Ecology 56: 119-131.

[19] Dandie, C.E., Burton, D.L., Zebarth, B.J., Henderson, S.L., Trevors, J.T., Goyer, C. (2008): Changes in bacterial denitrifier community abundance over time in an agricultural field and their relationship with denitrification activity. - Applied Environnmental Microbiology 74: 5997-6005.

[20] Depkat-Jakob, P.S., Brown, G.G., Tsai, S.M., Horn, M.A., Drake, H.L. (2013): Emission of nitrous oxide and dinitrogen by diverse earthworm families from Brazil and resolution of associated denitrifying and nitrate-dissimilating taxa. - FEMS Microbiology Ecology 83: 375-391.

[21] Djigal, D., Baudoin, E., Philippot, L., Brauman, A., Villenave C. (2010): Shifts in size, genetic structure and activity of the soil denitrifier community by nematode grazing. European Journal of Soil Biology 46: 112-118.

[22] Dodla, S.K., Wang, J.J., DeLaune, R.D., Cook, R.L. (2008): Denitrification potential and its relation to organic carbon quality in three coastal wetland soils. - Science of the Total Environment 407: 471-480.

[23] Enwall, K., Philippot, L., Hallin, S. (2005): Activity and composition of the denitrifying bacterial community respond differently to long-term fertilization. - Applied Environnmental Microbiology 71: 8335-8343.

[24] FAO (1998): World Reference Base for Soil Resources. FAO, ISRIC, ISSS, Rome, 91 pp.

[25] Gaillard, V., Chenu, C., Recous, S., Richard, G. (1999): Carbon, nitrogen and microbial gradients induced by plant residues decomposing in soil. - European Journal of Soil Science 50: 567-578.

[26] Garcia-Ruiz, R., Baggs, E.M. (2007): $\mathrm{N}_{2} \mathrm{O}$ emission from soil following combined application of fertiliser-N and ground weed residues. - Plant Soil 299: 263-274.

[27] Giannopoulos, G., van Groenigen, G., Pulleman, M.M. (2011): Earthworm-induced $\mathrm{N}_{2} \mathrm{O}$ emissions in a sandy soil with surface-applied crop residues. - Pedobiologia 54: 103-111.

[28] Gibert, O., Pomierny, S., Rowe, I., Kalin, R.M. (2008): Selection of organic substrates as potential reactive materials for use in a denitrification permeable reactive barrier (PRB). Bioresource Technology 99: 7587-7596.

[29] Hallin, S., Throbäck, I.N., Dicksved, J., Pell, M. (2006): Metabolic profiles and genetic diversity of denitrifying communities in activated sludge after addition of methanol or ethanol. - Applied Environnmental Microbiology 72: 5445-5452.

[30] Hallin, S., Jones, C.M., Schloter, M., Philippot, L. (2009): Relationship between Ncycling communities and ecosystem functioning in a 50-year-old fertilization experiment. - ISME Journal 3: 597-605.

[31] Hamonts, K., Clough, T.J., Stewart, A., Clinton, P.W., Richardson, A.E., Wakelin, S.A., O'Callaghan, M., Condron, L.M. (2013): Effect of nitrogen and waterlogging on denitrifier gene abundance, community structure and activity in the rhizosphere of wheat. - FEMS Microbiology Ecology 83: 568-584.

[32] Hedde, M., Lavelle, P., Joffre, R., Jiménez, J.J., Decaëns, T. (2005): Specific functional signature in soil macro-invertebrate biostructures. - Functional Ecology 19: 785-793.

[33] Henderson, S.L., Dandie, C.E., Patten, C.L., Zebarth, B.J., Burton, D.L., Trevors, J.T., Goyer, C. (2010): Changes in denitrifier abundance, denitrification gene mRNA levels, nitrous oxide emissions, and denitrification in anoxic soil microcosms amended with glucose and plant residues. - Applied Environmental Microbiology 76: 2155-2164.

[34] Huang, Y., Zou, J., Zheng, X., Wang, Y., Xu, X. (2004): Nitrous oxide emissions as influenced by amendment of plant residues with different C:N ratios. - Soil Biology and Biochemistry 36: 973-981. 
[35] IPCC (2007): Intergovernmental Panel on Climate Change. IPCC Fourth Assessment Report. Climate Change 2007, AR4. Cambridge University Press, Cambridge.

[36] Jingguo, W., Bakken, L.R. (1997): Competition for nitrogen during decomposition of plant residues in soil: effect of spatial placement of N-rich and N-poor plant residues. Soil Biology and Biochemistry 29: 153-162.

[37] Jones, C.M., Welsh, A., Throbäck, I.N., Dörsch, P., Bakken, L.R., Hallin, S. (2011): Phenotypic and genotypic heterogeneity among closely related soil-borne $\mathrm{N}_{2}$ and $\mathrm{N}_{2} \mathrm{O}-$ producing Bacillus isolates harboring the nosZ gene. - FEMS Microbiology Ecology 76: 541-552.

[38] Jones, D.L., Willett, V.B. (2006): Experimental evaluation of methods to quantify dissolved organic nitrogen (DON) and dissolved organic carbon (DOC) in soil. - Soil Biology and Biochemistry 38: 991-999.

[39] Kalbitz, K., Solinger, S., Park, J.H., Michalzik, B., Matzner, E. (2000): Controls on the dynamics of dissolved organic matter in soils : a review. - Soil Science 165: 277-304.

[40] Kandeler, E., LuxhØi, J., Tscherko, D., Magid, J. (1999): Xylanase, invertase and protease at the soil-litter interface of a loamy sand. - Soil Biology and Biochemistry 31: 1171-1179.

[41] Katz, R., Hagin, J., Kurtz, L. (1985): Participation of soluble and oxidizable soil organic compounds in denitrification. - Biology and Fertility of Soils 1: 209-213.

[42] Larsson, L., Ferm, M., Kasimir-Klemedtsson, A., Klemedtsson, L. (1998): Ammonia and nitrous oxide emissions from grass and alfalfa mulches. - Nutrient Cycling in Agroecosystems 51: 41-46.

[43] Majeed, M.Z., Miambi, E., Barois, I., Blanchart, E., Brauman, A. (2013): Emissions of nitrous oxide from casts of tropical earthworms belonging to different ecological categories. - Pedobiologia 56: 49-58.

[44] McGill, B.M., Sutton-Grier, A.E., Wright, J.P. (2010): Plant trait diversity buffers variability in denitrification potential over changes in season and soil conditions. - Plos One 5(7):e11618. doi:10.1371/journal.pone.0011618.

[45] McMahon, S.K., Williams, M.A., Bottomley, P.J., Myrold, D.D. (2005): Dynamics of microbial communities during decomposition of ${ }^{13} \mathrm{C}$ labelled ryegrass fractions. - Soil Science Society of America Journal 69: 1238-1247.

[46] Millar, N., Baggs, E.M. (2004): Chemical composition, or quality, of agroforestry residues influences $\mathrm{N}_{2} \mathrm{O}$ emissions after their addition to soil. - Soil Biology and Biochemistry 36: 935-943.

[47] Millar, N., Baggs, E.M. (2005): Relationships between $\mathrm{N}_{2} \mathrm{O}$ emissions and water-soluble $\mathrm{C}$ and $\mathrm{N}$ contents of agroforestry residues after their addition to soil. - Soil Biology and Biochemistry 37: 605-608.

[48] Millar, N., Ndufa, J.K., Cadisch, G., Baggs, E.M. (2004): Nitrous oxide following incorporation of improved-fallow residues in the humid tropics. - Global Biogeochemical Cycles 18, GB1032, doi:10.1029/2003GB002114.

[49] Miller, M.N., Zebarth, B.J., Dandie, C.E., Burton, D.L., Goyer, C., Trevors, J.T. (2008): Crop residue influence on denitrification, $\mathrm{N}_{2} \mathrm{O}$ emissions and denitrifier community abundance in soil. - Soil Biology and Biochemistry 40: 2553-2562.

[50] Mosier, A.R., Schimel, D.S., Valentine, D.W., Bronson, K.F., Parton, W. (1991): Methane and nitrous oxide fluxes in native, fertilized and cultivated grasslands. - Nature 350: 330-332.

[51] Mounier, E., Hallet, S., Chèneby, D., Benizri, E., Gruet, Y., Nguyen, C., Piutti, S., Robin, C., Slezack-Deschaumes, S., Martin-Laurent, F., Germon, J.C., Philippot, L. (2004): Influence of maize mucilage on the diversity and activity of the denitrifying community. Environmental Microbiology 6: 301-312.

[52] Murray, P.J., Hatch, D.J., Dixon, E.R., Stevens, R.J., Laughlin, R.J., Jarvis, S.C. (2004): Denitrification potential in a grassland subsoil : effect of carbon substrates. - Soil Biology and Biochemistry 36: 545-547. 
[53] Ndour, N.Y.B., Baudoin, E., Guissé, A., Seck, M., Khouma, M., Brauman, A. (2008): Impact of irrigation water quality on soil nitrifying and total bacterial communities. Biology and Fertility of Soils 44: 797-803.

[54] Palm, C.A., Sanchez, P.A. (1991): Nitrogen release from the leaves of some tropical legumes as affected by their lignin and polyphenolic contents. - Soil Biology and Biochemistry 23: 83-88.

[55] Patra, A.K., Abbadie, L., Clays-Josserand, A., Degrange, V., Grayston, S.J., Guillaumaud, N., Loiseau, P., Louault, F., Mahmood, S., Nazaret S., Philippot, L., Poly, F., Prosser, J.I., Le Roux, X. (2006): Effects of management regime and plant species on the enzyme activity and genetic structure of $\mathrm{N}$-fixing, denitrifying and nitrifying bacterial communities in grassland soils. - Environmental Microbiology 8: 1005-1016.

[56] Peralta, A.L., Matthews, J.W., Kent, A.D. (2010): Microbial community structure and denitrification in a wetland mitigation bank. - Applied Environmental Microbiology 76: 4207-4215.

[57] Philippot, L., Hallin, S., Schloter, M. (2007): Ecology of denitrifying prokaryotes in agricultural soil. - Advances in Agronomy 96: 249-305.

[58] Philippot, L., Čuhel, J., Saby, N., Chèneby, D., Chroňáková, A., Bru, D., Arrouays, D., Martin-Laurent, F., Šimek, M. (2009): Mapping field-scale spatial patterns of size and activity of the denitrifier community. - Environmental Microbiology 11: 1518-1526.

[59] Poll, C., Ingwersen, J., Stemmer, M., Gerzabek, M.H., Kandeler, E. (2006): Mechanisms of solute transport affect small-scale abundance and function of soil microorganisms in the detritusphere. - European Journal of Soil Science 57: 583-595.

[60] Rich, J.J., Heichen, R.S., Bottomley, P.J., Cromack, K., Myrold, D.D. (2003): Community composition and functioning of denitrifying bacteria from adjacent meadow and forest soils. - Applied Environmental Microbiology 69: 5974-5982.

[61] Rich, J.J., Myrold, D.D. (2004): Community composition and activities of denitrifying bacteria from adjacent agricultural soil, riparian soil, and creek sediment in Oregon, USA. - Soil Biology and Biochemistry 36: 1431-1441.

[62] Sadasivan, L., Neyra, C.A. (1988): Carbon sources for the in vivo nitrate reductase activity in Azospirillum brasilense cells. - In: Klingmüller, W. (Ed.), Azospirillum IV: Genetics, Physiology, Ecology. Springer-Verlag, Berlin, Heidelberg, pp. 131-140.

[63] Sarkodie-Addo, J., Lee, H.C., Baggs, E.M. (2003): Nitrous oxide emissions after application of inorganic fertilizer and incorporation of green manure residues. - Soil Use and Management 19: 331-339.

[64] Seneviratne, G., van Holm, L.H.J. (1998): $\mathrm{CO}_{2}, \mathrm{CH}_{4}$ and $\mathrm{N}_{2} \mathrm{O}$ emissions from a wetted tropical upland soil following surface mulch application. - Soil Biology and Biochemistry 30: 1619-1622.

[65] Sharma, S., Aneja, M.K., Mayer, J., Munch, J.C., Schloter, M. (2005): Diversity of transcripts of nitrite reductase genes (nirK and nirS) in rhizospheres of grain legumes. Applied Environmental Microbiology 71: 2001-2007.

[66] Sharma, S., Szele, Z., Schilling, R., Munch, J.C., Schloter, M. (2006): Influence of freeze-thaw stress on the structure and function of microbial communities and denitrifying populations in soil. - Applied Environmental Microbiology 72: 2148-2154.

[67] Smith, J.M., Ogram, A. (2008): Genetic and functional variation in denitrifier populations along a short-term restoration chronosequence. - Applied Environmental Microbiology 74: 5615-5620.

[68] Smolander, A., Kitunen V. (2002): Soil microbial activities and characteristics of dissolved organic $\mathrm{C}$ and $\mathrm{N}$ in relation to tree species. - Soil Biology and Biochemistry 34: 651-660.

[69] Tabazadeh, A., Santee, M.L., Danilin, M.Y., Pumphrey, H.C., Newman, P.A., Hamill, P.J., Mergenthaler, J.L. (2000): Quantifying denitrification and its effect on ozone recovery. - Science 288: 1407-1411. 
[70] Thioulouse, J., Chessel, D., Doledec, S., Olivier, J.M. (1997): ADE-4 : a multivariate analysis and graphical display software. - Statistics and Computing 7: 75-83.

[71] Throbäck, I.N., Enwall, K., Jarvis, A., Hallin, S. (2004): Reassessing PCR primers targeting nirS, nirK and nosZ genes for community surveys of denitrifying bacteria with DGGE. - FEMS Microbiology Ecology 49: 401-417.

[72] Velasquez, E., Lavelle, P., Barrios, E., Joffre, R., Reversat, F. (2005): Evaluating soil quality in tropical agroecosystems of Colombia using NIRS. - Soil Biology and Biochemistry 37: 889-898.

[73] Velthof, G.L., Kuikman, P.J., Oenema, O. (2002): Nitrous oxide emission from soils amended with crop residues. - Nutrient Cycling in Agroecosystems 62: 249-261.

[74] Wertz, S., Dandie, C.E., Goyer, C., Trevors, J.T., Patten, C.L. (2009): Diversity of nirK denitrifying genes and transcripts in an agricultural soil. - Applied Environmental Microbiology 75: 7365-7377.

[75] Wolsing, M., Priemé, A. (2004): Observation of high seasonal variation in community structure of denitrifying bacteria in arable soil receiving artificial fertilizer and cattle manure by determining T-RFLP of nir gene fragments. - FEMS Microbiology Ecology 48: 261-271. 